\section{Decision-Making Process in Society from the City Marketing's Point of View}

\author{
Ágnes Urbánné Treutz \\ Szent István University, H-2100 Gödöllö, Páter Károly u. 1. \\ tragnes@gmail.com \\ Zoltán Szabó \\ Szent István University, H-2100 Gödöllö, Páter Károly u. 1. \\ szabo.zoltan.phd@gmail.com
}

\begin{abstract}
One of the marketing's dynamically growing branches is the place marketing. More and more settlement realise the importance of it and use its instruments. The following research paper is about place marketing. Out of the three main target groups of the place marketing, we focus on tourists and examine their decision-making process and attitude.

Purpose - The aim of this article is to recognize the psychological factors, mainly the decisionmaking process and the attitude which influence the tourist's choice.

Methodology - The main purpose is to compare three consumer decision-making models using own research theme. The authors go through the importance of attitude in the decision-making process, different definitions, functions and how they are linked to tourist behaviors. It is crucial to see these decision-making processes because it is indispensable to explore the present consumer needs for the development of the society.

Findings - By the report, we gain an overview on the psychological factors behind the decisionmaking of one target group of the place marketing.

Value - It can be noticed that it is necessary to constantly follow the changes of consumer's decision-making process and attitude since they change from time to time as well as the travel behaviour. At the exploration of the potential tourist's decision-making process, it is important to note that the information source has a decisive role in the process. This work gives an insight into a target group of settlement marketing and the psychological factors behind the decision-making of the tourists. Knowing this information is indispensable for any settlements wishing to develop.
\end{abstract}

Keywords - place marketing, tourism, decision-making process, attitude, society, synergy, research

\section{Introduction}

The main goal of the research is to explore the presence of place marketing, the marketing strategy of the settlements in rural areas, how the marketing activities are presented in the Hungarian villages, how they adjusted the challenges of the present,
Decision-

Making Process in Society from the City Marketing's Point of View 
IJSR

4,2

what their plans are, which strategy they use. As the consumer awareness is more and more present in the consumer society, the focus is placed on it regarding the settlements from the viewpoint of the three main target groups. The reasons and arguments for them to choose a settlement for relaxation and recreation are of great importance to this thesis. In the present work, we examine the above-mentioned topic's theoretical background and adapt given tourism phenomena to it.

\section{Place marketing}

Nowadays, the significant part of the settlements does not place emphasis on marketing activities. The competition is ever intense between settlement and settlement, region and region, country and country (Tózsa, 2014). That is why it would be necessary to apply the place marketing activities consciously. Mostly, those settlements use the settlement marketing knowingly, which have more available sources, and those are mostly cities. Although this is not necessary meaningful that the place marketing activities can only be done from a bigger source, because from the three main target groups - the local residents, tourists and the entrepreneurs - it is not necessary to spend money on the cooperation between the local residents, to expand the localism, or to develop positive attitudes towards tourists. In this work, we present such planning model that has to be taken into consideration when defining the marketing activity and then narrow the research to the attitude of tourists and the psychological approach of the travel patterns.

When defining the marketing activities of a settlement, it is important to take into consideration the planning model which shows a planning process that has to be taken into account in conscious planning of the place marketing (Figure 1).

An operating marketing activity in a bigger geographical area (in subregion, county, region) can largely contribute to the success of a place's marketing activity. From the point of view of a settlement using this can lead to successful marketing communication and PR activity. At the same time, the activities of the settlement and its residents can react to the efficiency of a bigger geographical area. The necessary actions of the place marketing and the harmonisation and coordination of the instruments is basically the task of the municipality. However, it is necessary to involve other actively operating institutions, society and non-governmental organisations, because they can strengthen each other's actions which can contribute to the successful marketing activity of the settlement. From this view, the place marketing can be called social marketing. To achieve an appropriate marketing strategy, a comprehensive program has to be built which has to contain the relevant information and the background analysis, therefore, actual trends and micro- and macro- environmental searches (Michalkó, 2012; Piskóti, 2012). In the analysis, the external and environmental effects the macro-environment elements have to be considered (STEEP analysis): $\mathrm{S}$ - social, $\mathrm{T}$ - technological, E economical, E - environmental, $\mathrm{P}$ - political and legal environment. During the direct analysis of the market five fields have to be researched:

1. Image audit: the exploration of the formed image and the subjective picture of the target groups of external and internal marketing which are the two columns of place marketing. 


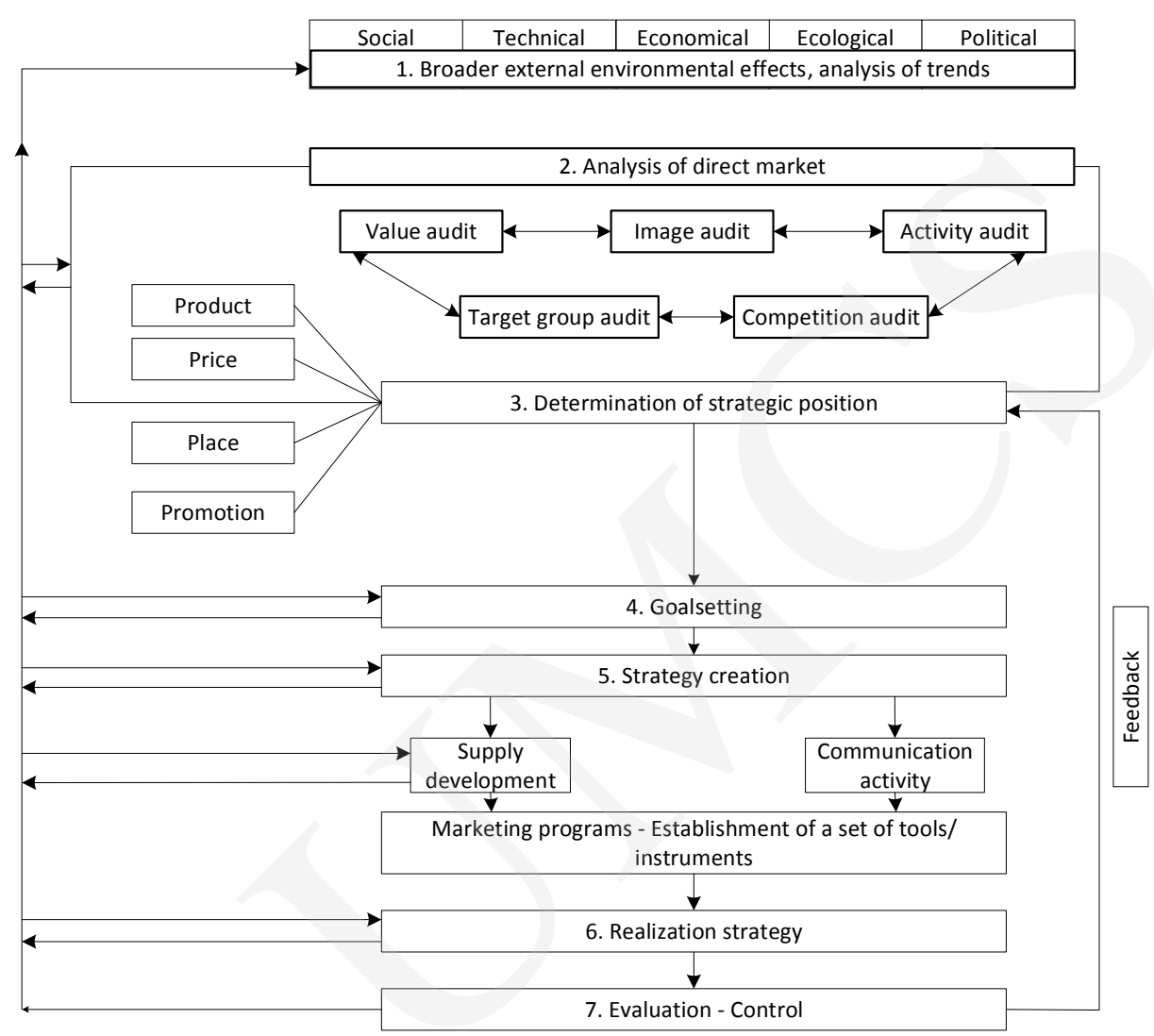

Figure 1.

The strategic planning and realization process of the place marketing

Source: based on Piskóti, 2012 (p. 70) own edition, 2015

2. Value audit: for suitable positioning and for the assessment of strengths and weaknesses, it is necessary to see the characteristics and values of the settlement.

3. Customer audit: customer expectations, customer's purchase behavior and the exploration of the characteristics of their decision-making processes.

4. Activity audit: analysis of the marketing activities done so far.

5. Competition audit: the evaluation prepared about the competition settlement.

For the settlement, it is necessary to define those goals which can be achieved according to the analysis. The primary goal of the settlements is to improve the quality of life and well-being. The elements related to these are the infrastructure, improvement of services, providing information for the residents, leaving the freedom of expression to them and providing an opportunity to take part in the life of the settlement. By doing so, the localism can be increased making the settlement attractive to tourists and the establishment process could start. Secondary goals could be built from primary ones, which improve the economic performance and the competitiveness of the settlement. 
IJSR

4,2
Figure 2.

The process of the consumer decision
During the strategy planning, it is important to take into account such factors as reaching the appropriate target groups and satisfying their needs (consumer orientation), following the competitors strategy and actions (competition orientation) and applying instruments that have to be practiced in harmony with strategy planning (instrument orientation). During the strategy development, it is necessary to define the financial, personal, task and time criteria. During the implementation of these, the immediate control and feedback possibility have to be created (Piskóti, 2012).

During the target group audit, the local residents, local entrepreneurs, potential tourists, institutions, political and professional organizations have to be examined. With the basic and descriptive variable of the marketing, it can be analysed whether the target groups segmented properly, how they behave and what they think about the settlement itself. Between the psychographic attributes of the consumers (basic variable), their attitude as well as interest, opinion and motivation derived from that can be explored and involved in the decisionmaking process (Piskóti, 2012; Piskóti et al., 2002). The attitude, motivation and the places visited by the tourists connected to the settlement belong to the descriptive variables. It is important to know how the individuals relate to the spot, because from the viewpoint of the environmental psychology based on the theory of spot-identity, it basically specifies the individual's life and the relation to the physical environment (Dúll, 2009; Piskóti, 2012). Starting at this point, we study the decision-making process and attitude of the tourists.

\subsection{The decision and the attitude of the tourist}

Tourists buy products or services as a result of a decision-making process. This process takes shorter or longer periods of time depend on the importance of the decision for an individual (Hofmesiter-Tóth, 2006). In services, in "purchasing" of a tourism spot three sequential stages are differentiated: the stage before the purchase, the purchase itself, the stage after purchase. The decision-making can be found in the before purchase stage. In the study, we present three decision-making models from the simplest one to the most complex. In particular cases, the model which shows the decision of the tourist always depends on the importance of the decision. Primarily, the goal is to compare these models interpreted from different viewpoints and place own research in the decisionmaking model. As in case of the purchase of services, the decision of a potential tourist is a result of a tourism decision process (Kenesei and Kolos, 2014). Three decisionmaking models based on Hofmeister-Tóth (Figure 2), Van Raaij (Figure 3) and Blackwell-Miniard-Engel (Figure 4) shall be presented now.

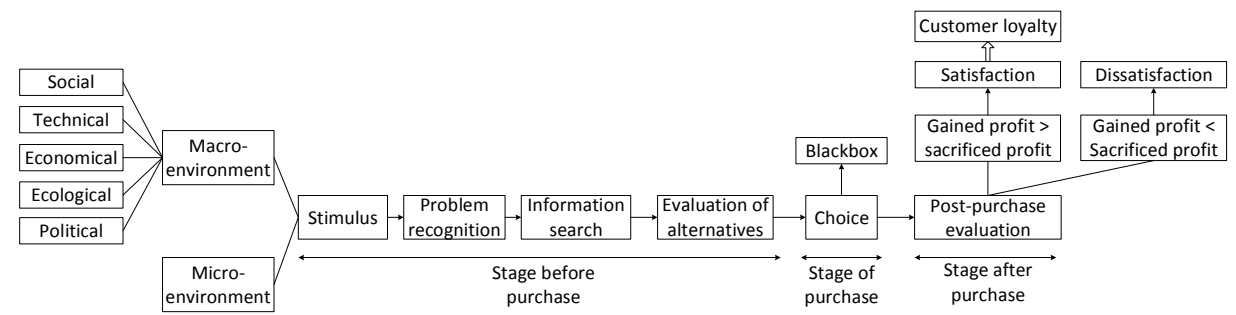

Source: based on Hofmeister-Tóth, 2003 in Kenesei and Kolos, 2014 (p. 92) own edition, 2015 


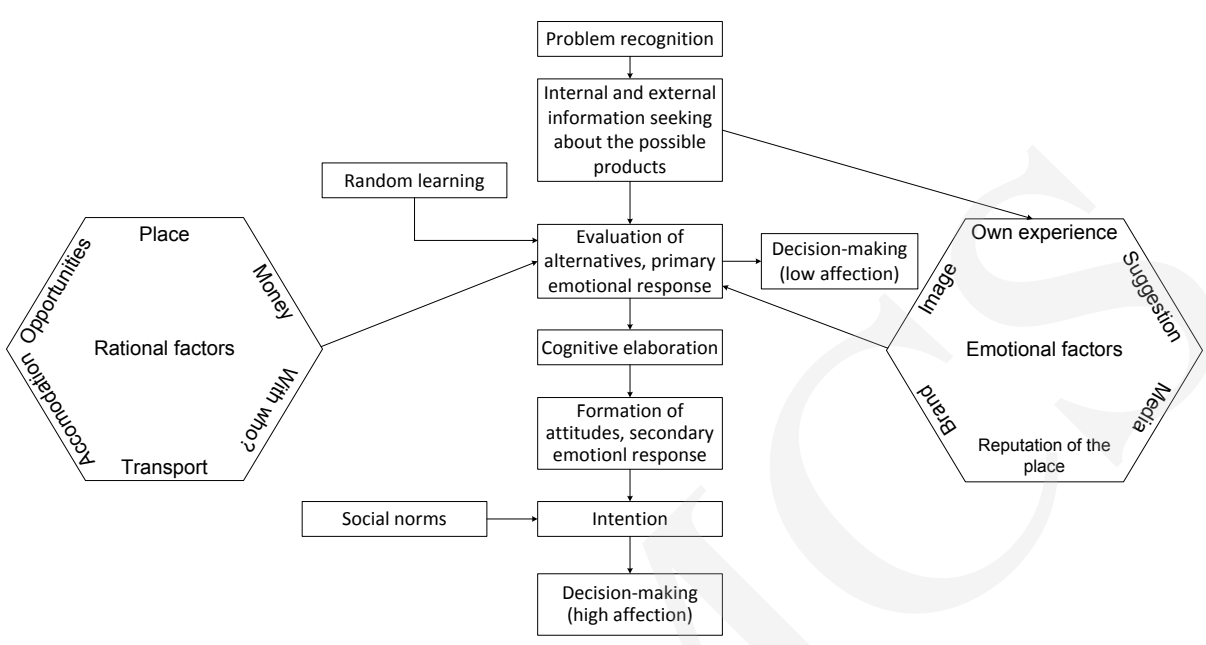

Figure 3.

The consumer decisionmaking model

Source: based on Hunyady and Székely, 2003 (p. 261) own edition, 2015

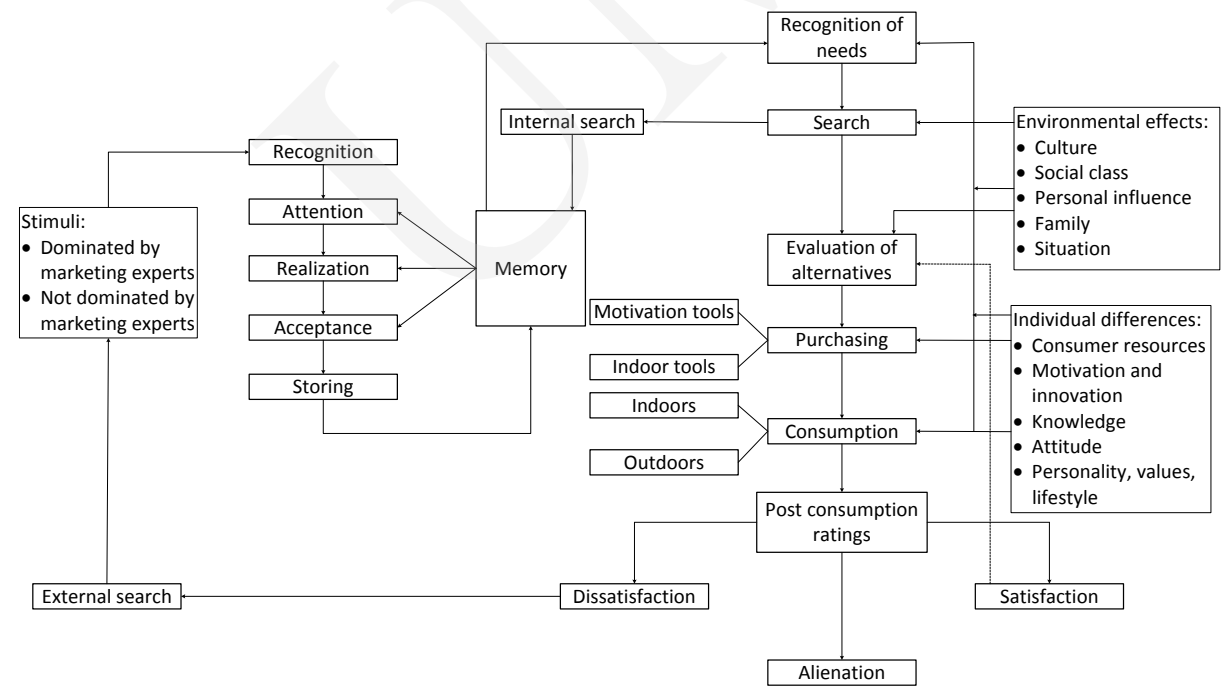

Figure 4.

Blackwell-Miniard-

Engel consumer decision-making model

Source: based on Pólya, 2013 (p. 28) own edition, 2015

Based on the figures, we can analyse the decision-making process of tourists. According to the models of Figures 1 and 3, the primary factor of the process marks the stimulus in the before purchasing stage which reaches the potential tourist. This stimulus can be social, physical or commercial and may have an important role in the individual's life, especially in these reference-groups, which can have significant effect on the purchasing decision. The physical stimuli are made up of the basic needs 
IJSR

4,2 from the bottom of the Maslow-pyramid (e.g. hunger, thirst). Commercial stimuli are those travel and holiday offers which make the individual want to go on holiday (Kenesei and Kolos, 2014). The complex model which can be seen in Figure 3 also takes into account the grouping of stimuli and divides them into two groups, namely dominated by marketing experts (equals with commercial stimuli) and not dominated by marketing experts (societal and physical stimuli) (Pólya, 2012). Perceiving the stimuli is a problem that raises in the individual. This can be found in all three models. For the tourist, the problem recognition will be the relaxation, holiday/travel demand. After that he/she will get some information about the adequate destination. The inner information seeking is the fame of the locations/settlements in the individual's own memory. External information seeking can be manifested from own experiences as it is about a known place, or from a third party. It can be friendly advice, mass communication (billboard, TV, radio, promotion videos on the Internet etc.) as well as advices by travel agencies and tourist information offices (Székely, 2003, 2014; Pólya, 2012).

In the subsequent evaluation, the positive, negative and unique features are compared based on certain criteria (e.g. the appearance of the place, usability, symbolic values, price, service quality, etc.) in case of rational decision. The evaluation can be systematic or incidental. The complex model shows the processing of information in the following steps: the recognition is followed by attention, then understanding, acceptance and finally the storage. The evaluation is influenced by more factors, like consumer ideal, demographic features, time factor and pleasant feelings from the past which can create nostalgic memories (emotional characteristics). The values of the consumer also influence the valuation process which is affected by the narrower and broader cultural environment. In case of services, the difference from the products is that the consumer has more information because a service (in this case the place itself) has a bigger uncertainty (Kenesei and Kolos, 2014; Székely, 2003; Pólya, 2012). The fluctuation of services (the performance is fluctuating in time and space), intangibility (not a physical product so cannot be perceived by senses), perishability (cannot be stored) and inseparability (the consumption has to happen in the same space and time) make the consumer more willing to choose the right one. The judgement essentially forms the potential tourist's attitude and beliefs to the place (Székely, 2003; Horváth, 2008).

Authors' own research based on the above-mentioned issues is embedded into the model of Hunyady and Székely from 2003 on the consumer decision-making model (Figure 3). During the decision-making process, numerous subdecisions have to be made which form the whole process. According to this, it has to be determined with whom, where, when and which influential factors make the tourist travel (Davis, 1970; Árpási, 2012 in Nyári, 2012). Based on these, the evaluation of alternatives is emphasized. During the inner and outer information acquisition, on one hand, the appearance of the individual's own emotions and experiences can be seen and, on the other hand, his/her own behaviour, what he/she thinks about the place. These emotional characteristics are evaluated simultaneously with the rational arguments. I will study this process in the future deeply to know what the weight of the different factors which takes part in the evaluation process. From the rational side, the factors are the following: place, cost, with whom the tourist goes on a holiday, transportation, accommodation and things 
which can help the tourist relax in any place. The emotional factors are the following: the potential tourist's own experience, suggestions from friends and acquaintances, the influence of media, what the individual thinks about the place, the brand the place can be connected to and the image of the place.

To observe how a tourist chooses a destination, we have to take a closer look at the consumer's behaviour. It is necessary to size up the attitude of the tourist linked to the particular place and what motivates him, which can help him/her make the decision (Székely, 2003). The potential tourist usually has less information about the previously unvisited place. When choosing a destination, the most decisive elements are the image and attitude, not the real supply of the place (Um and Crompton, 1990). The definition of attitude has been introduced at first in social psychology in order to better understand the human behaviour (Fischbein and Ajzen, 1975). It can be stated that ,attitude is the combination of the individual's belief and its strength" (Farris et al., 2008). According to another definition ,attitude signs an individual permanently favourable or unfavourable evaluation, feeling or acting tendency connected to certain objects or conceptions" (Krech et al. 1962 in Kotler and Keller, 2006). There are interpretations which refer to the consequence of attitude which is the motivation. This makes the individual act: „the attitudes create certain moods: pleasure or displeasure towards an object and intention to the object or the opposite of it" (Kotler and Keller, 2006). According to a complex definition, ,attitude is a mental, neural standby state based on the experience which impacts controlling or dynamic effect of the individual's reaction towards those objects and situations to which the attitude is related" (Hofmesiter-Tóth, 2006). What is common in these definitions, is the fact that they indicate a state which can be a belief, feeling or controlling impact about an object or a situation associated with positive or negative attributes.

Those beliefs which have impact on the tourist about the characteristics of the place, also have an impact on his behaviour. It can be formed as a consequence of learning or a previous act. This knowledge is frequently filled with emotion. The discrepancy between attitude and supposition is that the attitude contains general cognitive valuation, line of action, emotions, feelings and appraisals in connection with a specific subject, in this case, with a place. It is determined by the positive or negative characteristics of the specific place. The self-image and values of the tourist have impact on the interest about a specific place.

The above-mentioned positive or negative attitude can be formed from the effect of different stimuli. To these stimuli the responding reaction and its handling can be divergent. In case of perception as long as the consumer are reached by one or more stimuli at the same time for a long while on several occasions he can form positive or a negative attitude. If the information constantly reaches the consumer without conscious perception, it will result in inverse ratio to attitude and the number of repetition. Due to boredom and informationoverload, the consumer will be less motivated and it may result in negative responses (Székely, 2003). In case of tourists, there is little chance that they reach the level of boredom, because the number of advertisements which advertise potential recreation places on TV, on the radio or on billboards is very limited. All these tools have an important role in forming and changing the attitude. The changing of attitude depends on the functions performed by it. The classical functions of the attitude are the following:

\author{
Decision- \\ Making Process \\ in Society \\ from the City \\ Marketing's \\ Point of View
}


IJSR

4,2
1. Social adapting (utility/utilitarian/adaptive) function: the coordination of behavior to get less or more confirmation. The utility of attitude mostly is the social adapting value. For example, the given tourist does not prefer Syria as a destination. It is not against people living in the country, it is rather about associating the conflict in the country with the given territory.

2. Self-protection function: protection of judgements and suppositions that have been created in the consumer's mind by not letting it be attacked with different realizations. This facilitates to defeat the inner conflicts of the individual with the help of his own attitude. This is a kind of defence mechanism, which can be changed with difficulty, because of attitudes derived from the inner needs of a person. For example, a male tourist guide provided by a travel agency can raise doubt in a female tourist about whether or not she will be treated as an equal by him. It can derive from a life situation when she has not been treated equally as a woman (work, family, etc.) but it can also derive from an experience which made her feel that the representatives of the two genders are not treated equally in religion and culture.

3. Value expression (self-realization) function: with the positive attitude, the consumer can show his values. It is a more emotional function which can help the individual know his/ her self-identity which leads to self-enhancement. One forms an attitude to justify the behaviour, which changes when the individual has to internalize a new norm due to an open pressure. For example, a tourist loves summer clothing and by that he can express his personality. When he goes to a church, the rules and norms have to be taken into account, and it is necessary for him to wear clothes that cover the shoulders.

4. Cognitive (economic/cognition) function: helps with easier understanding and transparency of the environment of the consumer. As in science, the raw facts are so rich in life, thus those cannot be grabbed and processed in its entirety. With different generalizations we put them into groups in order to make the contexts simpler. Those form attitudes which can become stereotypes. In case of that function, the consumer changes his/her attitude easier by the recognition of new information, new experiences. For example, the tourist reluctantly goes on holiday to a place where there is an active volcano. With the help of technology and the fast information flow it is easy to reach those scientific information which show when the last eruption was, and give forecast related to the next eruption. If the consumer is aware of these information, it might change the attitude toward the place and the existence of a volcano there will have a smaller impact on the decision (Halász et al., 1979; Székely, 2003).

An attitude can supply more function, more function can supply one attitude (Halász et al., 1979). Depending on these functions, attitudes can change. The elaboration of the probability model is one of the methods which can help study the change of attitudes based on the level of extent of the consumer's involvement. In case the consumer is strongly affected, he/she compares pros and cons of his/her attitude to the acquired information. In case he/she is weakly affected, the comparing evaluation is not done (cognitive elaboration). In the latter case, it is less tending for the attitudes to change in contrast with the previous, where new information helps the individual elaborate on the increasing amount information, so the consumer's supposition and attitude can 
change (Székely, 2003). Moreover, it is easier for the customer to accept a standpoint to a current attitude than a completely different one (Weber, 1991). In case of travelling and recreation, the involvement of the customer probably will be strong, because according to the characteristics of the services, the services are inseparable in time and place, the consumer has to experience it, or it is otherwise lost. Thereby, the only way for the tourist to resort the service preferred by him is to travel to the chosen destination. What the consumer purchases, those practices, symbols will be acquired so he will be what he consumes (Dúll, 2009). Therefore, he feels the different effects on his skin so he will be strongly affected. Those components can lead to any change in attitude - so in consumption - which can be transformed easy, which means they are not fixed (Bányai and Novák, 2011). Ergo, in case of a consumer's destination choice, the attitude can only be changed if there is no strong attachment to the given place.

Connected with studying the attitude of tourists, is the review, the authors of this thesis conduct on the travel habits of the Hungarian population, in what proportion the households choose domestic trips or trips abroad and how long they last. An exploratory research done by the Hungarian Tourism Ltd. in December 2010 was used. The survey has been carried out among 1000 Hungarians over 18 years of age. The research is the part of a research series started in 2000 where the results come from data of the respondents surveyed between December 2009 and November 2010. 67.6\% of the respondent Hungarian households took part in a one-day trip, whilst $60.9 \%$ took part in more than one night journey. According to the results of the survey in case of one-day trips, the domestic Central-Transdanubian turistic region (22\%) and Austria $(72.4 \%)$ were the most visited place among the Hungarians. In case of domestic journeys, the most people had one-day trips in July and August, whilst in case of abroad destinations, the most people took part in a one-day trips in October and January. The motivation for the one-day domestic trips are shopping $(42.3 \%)$ and visiting relatives $(18.3 \%)$. The motivation for the one-day abroad trips was the same but for $26.9 \%$ the motivation for the trip was shopping or sightseeing for $32.2 \%$. Generally, $65.5 \%$ of the one-day travelers do not acquire information neither before the trip, nor during the trip. This tendency represents a high percentage between the domestic travelers and abroad travelers as well (over 50\%). The most popular destinations among the Hungarian households, in case of travels for more than one night are: Lake Balaton for domestic (22.3\%), and Austria (13.2\%), Croatia (12.2\%) and Romania (11.4\%) for abroad journeys. The latter data changed from 2011 to 2012 in that the most popular destination for more than one night journeys was Austria (15.4\%) then Romania (13.9\%) which is followed by Italy (10.8\%). It seems that $35.4 \%$ of the participants of more than one night travels do not require tourist information neither before the journey nor during the journey. Of respondents who only participate in domestic journeys, $46.2 \%$ do not acquire information at all, of those who just took part in an abroad trip $-23.3 \%$ and of those who took part in both trips $-15.3 \%$ (source: neta.itthon.hu/).

In the biggest proportion, only the abroad travelers acquire tourism information only before the journey (53.4\%) like those who engaged in domestic and abroad journeys. They acquired information mostly before and during the journey. This data does not completely demonstrate the attitude of Hungarians towards travelling. In Hungary, the most part of the population is price-sensitive. If the consumer has financial possibility but

Decision-
Making Process
in Society
from the City
Marketing's
Point of View


IJSR

4,2 has to choose between domestic and abroad journey, the potential Hungarian tourist will prefer to go abroad. However, when examining the decision-making process, it becomes clear that in case of one-day trips, tourists do not acquire information. Most domestic travelers choosing a trip for more than one night, do not acquire information about the destination, however, more than half of the respondents (53.8\%) acquire information before or during the journey. Those who take part in abroad journeys or domestic and abroad ones, more often get information before and during the trip. The first and biggest information source is the Internet, which is underpinned by the result of a former study from 2007 which dealt with the Hungarian people's travelling behaviour connected to consumer behaviour. According to that study, more information sources are used by the consumers for the decision-making and the most significant is the Internet. Besides this, the information given by friends and acquaintances also influence the process. More than $50 \%$ of the respondents marked those two information sources (http://neta.itthon. $\mathrm{hu} /$; Neulinger et al., 2009). According to the surveys, it can be established that the opinion of the acquaintances are important to the Hungarians, but it does not exceed the possibilities of the Internet. However, information from friends and acquaintances because of personal communication and more confidence - are more intensive and have a bigger role in influencing consumer's attitude.

Because of the high proportion of domestic journeys, the Hungarian attitude towards rural areas is worth mentioning. Here, in case of more than one night journeys next to visiting relatives, the beach holiday and bungalow holiday was the biggest motivation (http://neta.itthon.hu/). According to Megyesi (2007), based on his own survey, the attitude of Hungarian population towards the countryside is twofold. According to the first one, the countryside equals agriculture, the other one highlights the nature and the presence of traditions. Those attitudes have been present in the past and in the present as well (Megyesi, 2007).

\section{Summary}

Overall, it can be noticed that it is necessary to constantly follow the changes of consumer's decision-making process and attitudes because they change from time to time, as does the travel behaviour. The information source, what he trusts, and furthermore, whether the final result is the consequence of an emotional or a rational decision all have a decisive role in the potential tourist's decision-making process. The attitude is also closely integrated in the decision-making process which has a crucial role in the determination of the destination. The work gives an insight into a target group of settlement marketing and the psychological factors behind the decision-making of the tourists. Knowing this information is indispensable for any settlements wishing to develop. 


\section{References}

Árpási, K. (2012). A szabadidö eltöltésére vonatkozó családon belüli döntéshozatali preferenciák, in: D. Nyári (Ed.) A VI. Magyar Földrajzi Konferencia, a MERIEXWA nyitókonferencia és a Geográfus Doktoranduszok Országos Konferenciájának Tanulmánykötete. Szegedi Tudományegyetem Természeti Földrajzi és Geoinformatikai Tanszék, Szeged.

Bányai, E. and Novák, P. (2011). Online üzlet és marketing. Akadémiai Kiadó Zrt., Budapest.

Davis, H.L. (1970). Dimensions of marital roles in consumer decision making, Journal of Marketing Research, Vol. 7, pp. 168-177. DOI: http://dx.doi.org/10.2307/3150105

Dúll, A. (2009). A környezetpszichológia alapkérdései, Helyek, tárgyak, viselkedés, L’Harmattan, Budapest.

Farris, P.W., Bendle, N.T., Pfeifer, P.E., Reibstein, D.J. (2008). Marketingmérések, Scolar Kaidó, Budapest.

Fischbein, M. and Ajzen, I. (1975). Belief, attitude, intention and behavior: An Introduction to Theory and Research, Addison-Wesley Publishing Company.

Halász, L., Hunyady, G., Marton, L.M. (1979). Az attitüd pszichológiai kutatásának kérdései, Akadémiai Kiadó, Budapest.

Hofmeister-Tóth, Á. (2003). Fogyasztói magatartás, Aula Kiadó, Budapest.

Horváth, Á. (2008). Marketing, Szent István Egyetem, Gödöllő.

Hunyady, G. and Székely, M. (2003). Gazdaságpszichológia, Osiris Kiadó, Budapest.

Kenesei, Z. and Kolos, K. (2014). Szolgáltatásmarketing és - menedzsment, Alinea Kiadó, Budapest.

Kotler, P. and Keller, K.L. (2006). Marketingmenedzsment, Akadémiai Kiadó, Budapest.

Krech, D., Crutchfield, R.S., Ballachey, E.L. (1962). Individual in Society, in: P. Kotler and K. L. Keller (Eds.) (2006), Marketingmenedzsment, Akadémiai Kiadó, Budapest, McGrow-Hill, New York.

Megyesi, B. (2007). A magyar lakosság vidékkel kapcsolatos attitűdjei, in: I. Kovách (Ed.), Vidékiek és városiak, A tudás - és imázshasználat hatásai a vidéki Magyarországon, L'Harmattan - MTA PTI, Budapest, pp. 27-43.

Michalkó, G. (2012). Turizmológia, Akadémiai Kiadó Zrt, Budapest.

Neulinger, Á., Kelemen, K., Simon, J., Hofmeister-Tóth, Á. (2009). Fogyasztói magatartás a hazai utazási szolgáltatások piacán, Turizmus Bulletin, Vol. 8 No. 4, pp. 44-55.

Piskóti, I. (2012). Régió - és településmarketing. Marketingorientált fejlesztés, márkázás, Akadémiai Kiadó, Budapest.

Piskóti, I., Dankó, L., Schupler, H. (2002). Régió - és településmarketing, KJK-KERSZÖV Jogi és Üzleti Kiadó Kft., Budapest.

Pólya, É. (2012). Családon belüli vásárlási döntési szerepek és folyamatok, Doktori értekezés, Szent István Egyetem, Gödöllö.

Székely, M. (2003). A fogyasztói magatartás alapjai: A lélek - és a gazdaságtan alapfeltevései a fogyasztásról, in: G. Hunyadyand and M. Székely (Eds.), Gazdaságpszichológia, Osiris Kiadó, Budapest, pp. 231-296.

Tózsa, I. (2014). Turizmus és településmarketing. Budapesti Corvinus Egyetem Gazdaságföldrajz és Jövőkutatás Tanszék, Budapest, pp. 129-158.

Um, S. and Crompton, J.L. (1990). Attitude determinants in tourism destination choice, Annals of Tourism Resarch, Vol. 17, pp. 432-448.

DOI: http://dx.doi.org/10.1016/0160-7383(90)90008-F

Weber, A.L. (1991). Introduction to Psychology, HarperCollins Publishers, New York. A magyar lakosság utazási szokásai, 2010. Retrieved January 23, 2015 from

http://neta.itthon.hu/szakmai-oldalak/belfoldi-turizmus/belfoldi-turizmus\#2013

Decision-
Making Process
in Society
from the City
Marketing's
Point of View


IJSR

4,2

\section{Biographical notes:}

Ágnes Urbánné Treutz has graduated BA at Szent István University in 2011 with the major of Trade and Marketing. She finished her Master degree in 2013 as regional and environmental economist. She is now a PhD Student at Szent István University in Hungary at the Marketing Management Department. Her main fields of research is place marketing and tourism marketing.

Zoltan Szabo has graduated at GAU in 1998 with the major of Agricultural Marketing. $\mathrm{He}$ finished his $\mathrm{PhD}$ in wine marketing and gained the MBA at Webster University in 2007. He is now head of the Marketing Management Department at Szent Istvan University Hungary. His main fields of research are wine marketing, tourism marketing, place marketing and regional marketing. 